compilation of a flora of Asiatic Russia under the direction of Prof. Boris Fedtschenko, chief of the Herbarium, and some other specialists and volunteers. Local floras of Turkmenistan and south-east Russia, among others, are also being worked up. Recently much work has been done on South American plants. Herbarium specialists are preparing monographs on Tulipes, Artemisia, Tamarix, Gramineæ, Leguminosæ and many other groups of plants. Every year most of the botanists of the Herbarium staff go to the different countries of Russia and adjacent Asia for botanical and geographical studies; this year some are in Turkmenistan, Persia, and in Mongolia.

The cryptogamic department, formerly a part of the Herbarium, is now separated under the direction of A. A. Elenkin and is carrying on intensive studies upon Russian mosses, lichens, algæ, and fungi.

The geo-botanical department, under the direction of Prof. N. Kuznezov, has in hand the making of a geo-botanical map of the European part of Russia. This map is now ready on the scale of $I: 2,500,000$, and the staff of the geo-botanical department is working on the more detailed maps.

One of the most recent departments of the Botanical Garden is that of acclimatisation, under the direction of W. Sukatshef. The purpose of this department is to introduce into cultivation new and interesting plants from different parts of Russia and from adjoining countries. This department has special grounds for the cultures of perennial, herbaceous, and woody plants, as well as for the experimental nurseries of different varieties of fruiting trees and shrubs.

The museum of the Garden since I89I has been under the direction of $\mathrm{N}$. Monteverde ; it has received very large and interesting collections in the last few years. A special section of the museum is working on the study of medicinal plants, which is of great importance for human welfare and health.

There are two departments of the Garden which deal chiefly with practical problems : one is that of seed studies, where numerous analyses of seeds and germination tests are made. Scientific studies on seeds are also carried on. Two important and interesting problems have recently been worked out: the first upon the difference between winter and summer wheat and barley, the other in distinguishing correctly between living and dead seeds.

The other department with many practical problems is that of phytopathology, in which specimens of plant diseases sent from different parts of Russia are studied, and new plant parasites are described.

The department of plant physiology is working on several physiological problems, chiefly dealing with assimilation. The department of hydrobiology is carrying on studies upon the cryptogamic plants of the plankton of Russian rivers and lakes, particularly in the Leningrad region.

The Library of the Garden is the richest botanical one in the country, and it has a large stock of recent and back publications of the Garden for exchange.

The Garden has now three affiliated gardens: one of these is in a suburb of Leningrad, another in Omsk (Western Siberia), and the third in Vladivostok (Eastern Siberia).

The results of the scientific studies of the staff are published by the Garden in numerous botanical articles and larger works, although handicapped by the very small sums granted for publications. The principal and the oldest publication of the Garden is Acta Horti Petropolitani, started in I872, now under the direction of $B$. Fedtschenko. This journal contains chiefly voluminous works such as those of Komarov, Fedtschenko, Roshewitz, and other botanists of the Garden. The Bulletin of the Garden is chiefly for the publication of short articles on all branches of botany. The Morbi Plantarum and the Annals of the Department for Seed. Study are the special organs of the departments of plant pathology and of seed study.

Recently the Garden has commenced the publication of three new periodicals: Conspectus litterature botanice-an abstract journal chiefly for Russian botanical literature. Without this it would be very difficult to know of all the botanical publications which are now appearing in large numbers every year in different parts of Russia. Another new publication of the Garden is Notula systematica ex Harbario; this contains chiefly descriptions of new species and genera from all parts of the world from the specimens in the Herbarium of the Garden. In this publication, as well is in the others, contributions are received both from the staff of the Garden and from botanists in other parts of Russia (including Ukrainia, Caucasus, Turkestan, Siberia). A similar publication, Notule systematica ex Instituto Cryptogamico, deals with the cryptogams.

Every year the Garden sends botanical expeditions to study plants in different parts of Russia and Asia. The most important journeys have been into Central Asia, Transbaicalia, Mongolia, Persia, etc.

The facts given above show that the Botanical Garden in Leningrad is at the height of its activities in botanical study, and that excellent opportunities are afforded for solving important problems. Now, as formerly, the Garden is in correspondence with the chief botanical institutions of the world. Any question upon the flora of Russia or Russian botanical literature, or regarding botanical research in Russia, will be gladly answered from the Garden or by the present writer.

\title{
Stone-dusting Tests in England and America.
}

THE Safety in Mines Research Board has just issued a pamphlet ${ }^{1}$ which will be of great interest to mining engineers both in the United States and in Great Britain. It contains the first fruits of that arrangement for co-operative research which was made last year between the U.S. Bureau of Mines and the British Safety in Mines Research Board, and is published under the joint names of the two directors of research, Mr. G. S. Rice and Prof. R. V. Wheeler.

The investigations begun in the large steel gallery at Eskmeals by the Home Office Committee on the efficacy of "stone-dusting " in preventing coal-dust ${ }^{1}$ Mines Department. Safety in Mines Research Board. Paper No. 13. Stone Dust as a Preventive of Coal Dust Explosions. Comparative Tests. By G. S. Rice and R. V. Wheeler. Pp. I5. (London: H.M.S.O., 1925.) $3^{d}$. net.

NO. 2926, VOL. I I 6] explosions were soon supplemented by the researches made in the experimental mine at Bruceton, near Pittsburgh, by the Bureau of Mines. But the results obtained at the two stations showed differences which led to the assumption that the Pittsburgh coal was much more sensitive to ignition than the Altofts Silkstone used as the standard at Eskmeals. Such an assumption rendered futile any comparison between the two sets of experiments, and the conclusions drawn in one country could not be applied, it was thought, to the conditions of the other. The first step in co-operation was taken when a consignment of Altofts Silkstone was sent to Bruceton, and a similar supply of Pittsburgh coal was received at Eskmeals. The experiments carried out at the two 
stations now described show that the behaviour of the two coal-dusts is very much the same when the experimental conditions are similar; and the conclusion is drawn that the differences between the results at the two stations are due to the greater severity of the American tests. At Bruceton the experimental mine is driven into an actual coal-seam and has a cross-section of 58 square feet; the powdercharge used as the source of ignition is $4 \mathrm{lb}$.; the dust is spread on cross-beams near the roof as well as on side shelves and on the floor. At Eskmeals the original experiments were carried out in a circular steel gallery of $7 \frac{1}{2}$ feet diameter; the later comparison-experi. ments were made in a smaller steel tube 38 inches in diameter with a charge of $28 \mathrm{oz}$. of blasting-powder.

Again, in a number of experiments where small percentages of gas were present with the dust, the Americans used their natural gas containing, besides methane, some I $_{5}$ per cent. of higher paraffinsethane, propane, etc.--which ignite more readily than the pure methane derived from coal. The conditions both of ignition and of propagation were therefore more favourable at Bruceton than at Eskmeals. It is a clear gain to have established that the standard coals used at the two stations are so nearly similar that the varied experience obtained in one country can be applied, under the same working conditions, to the other.

\section{The Data for Weather Forecasting.}

METEOROLOGISTS are being urged to extend the periods covered by their forecasts, and in a recent paper ${ }^{1}$ Exner has worked out the correlation coefficients between contemporary monthly pressure departures at Stykkisholm (Iceland) and those of seventy other places distributed over the earth. The data handled are from I887 to I9I6, and the monthly departures of pressure and temperature for all the stations are most generously printed at length for the benefit of other workers : their mean square values also are tabulated and briefly discussed.

Relationships in the North Atlantic had previously received considerable attention, from Exner and others; so the results in the present paper, though of the greatest value, are not in general surprising. There is a region of close positive relationship extending from Baffin's Bay to Norway, and one of negative relationship near the Azores, in winter extending from the Bermudas to Italy, with an outlying region in Japan: with places in the southern hemisphere there is little connexion.

An important feature of the paper is its hope of inauguration of a programme of calculation of which the present 840 coefficients form but a small fraction. If all were worked out, there would be more than I 20,000 contemporary monthly relationships between I 43 variables, $7 \mathbf{I}$ of pressure and 72 of temperature. But, though Exner does not suggest any extension, this would not be enough; for with many places, especially in the southern hemisphere, there are essential effects produced after six months. These non-contemporary effects are vital for forecasting, and if we were to correlate a monthly value at one place with values from seven months before to seven months after at other places, we should multiply our coefficients by 15 .

There is much to be said for the plan adopted in Walker's two papers on world-weather of using quarterly values. With twenty " centres of action," the total number of coefficients, including time intervals of $\pm 2, \pm 1$, o quarters, is then 7600 , and a number I "Monatliche Luftdruck- und Temperaturanomalien auf der Erde : d. Akad. d. Wiss. in Wien, Abt. IIa, $\mathrm{r} 33$ Bd., 7 u. 8 Hefte, 1924. of stations may be added without a prohibitive amount of labour.

Exner's argument for dividing the year into twelve rather than four periods is that he proposes in this way to distinguish real from accidental relationships, the former being distinguished by a smooth, regular series of values during the year. ${ }^{2}$ But it has not been shown that statistical criteria applied to quarterly values have failed; and as the largest of twelve errors in Exner's coefficients has a probable value of 0.35 , a smooth series is as accidental as a fairly irregular one.

It is a matter of sincere congratulation that Exner's great ability is being directed to the elucidation of these questions of commercial as well as scientific importance.

$$
2 \text { " Regelmassige Verlauf durch die zwölf Monate," loc. cit. p. } 329 .
$$

\section{University and Educational Intelligence.}

CAMBRIDGE.-Mr. J. A. Chadwick has been awarded the Arnold Gerstenberg Studentship (for moral philosophy and metaphysics). Mr. Chadwick took the Natural Sciences Tripos Pt. I. in I923 and the Moral Sciences Tripos in I925; he was recently elected to a fellowship at Trinity College.

A grant of $50 l$. has been made to Miss Marion F. Bridie of Birmingham to facilitate her research as to the ultimate effect of education among the mentally deficient.

LeEdS.-The West Yorkshire Coal Owners' Association has given $25,000 l$. to the appeal fund. In accepting the gift, the council of the University passed a resolution stating that the success of the University's Department of Mining is due in large measure to the co-operation of the industry, not only in the form of subscriptions, but also through assistance given on the Mining Advisory Committee, by facilities offered to students for gaining practical experience, and in other ways. The annual grants made through the Association amount to nearly Io,oool., and these are to be continued at the rate of Ioool. a year.

The following appointments have been made:Mr. W. Murphy to be demonstrator in experimental physiology, and Dr. Arthur Raistrick to be research assistant in geology.

London.-Mr. Hilary Jenkinson has been appointed as from August I last to the University readership in diplomatic and English archives tenable at King's College. Mr Jenkinson is the editor of volumes of the Surrey Archæological Society and Surrey Record Society, and is the author of numerous works on palæography.

It has been resolved to institute an M.A. degree in geography for external students.

The following doctorates have been conferred:D.Sc. (Chemistry), Mr. J. M. Johlin (University College), for a thesis entitled "The Surface Concentration of Colloids at a Liquid-Gas Interface"; D.Sc. (Entomology), Mr. H. P. Hacker, for a thesis entitled "How Oil Kills Anopheline Larvæ," and other papers.

THE effect on school-holidays and on the various branches of education in every country of a fixed date for Easter is being investigated by the League of Nations' Special Committee of Enquiry into the Reform of the Calendar. This Committee, on which the Rev. T. E. R. Phillips, Secretary of the Royal Astronomical Society, represents Great Britain, has been devoting particular attention to the question of the fixing of Easter and now wishes to conclude its general inquiry. While the need of fixing this festival

No. 2926 , vOL. 116$]$ 